\title{
NOTEWORTHY RECORDS OF MAMMAL FROM CAMPECHE, MÉXICO
}

\author{
JORGE A. VARGAS-CONTRERAS ${ }^{1,2}$, J. RAFAEL HERRERA-HERRERA ${ }^{3}$ \\ ANDJ.ENRIQUEESCOBEDO-CABRERA ${ }^{4}$
}

${ }^{1}$ Instituto de Ecología, Universidad Nacional Autónoma de México, Ap. Postal 70-275, 04510, México,D.F.e-mail: jalbino@miranda.ecologia.unam.mx

${ }^{2}$ Facultad de Ciencias Químico Biológicas, Universidad Autónoma de Campeche, Av. Agustín Melgar s/n, Colonia Buenavista, 24030 Campeche, Campeche, México

${ }^{3}$ Unidad Académica Multidisciplinaria Agronomía y Ciencias, Centro Universitario Victoria, Ciudad Victoria, Tamaulipas, México

${ }^{4}$ El Colegio de la Frontera Sur (ECOSUR), Museo de Zoología, Unidad Chetumal, Av. Centenario km 5.5, Chetumal, Quintana Roo, 77900, México

Key words: Oppossum, Bat, Tayra, Mouse, Calakmul, Campeche.

Tropical forests are seriously threatened due mainly to its transformation into agricultural, forestry, and cattle-production areas to suit the needs of the expanding human population. Wildlife reserves have been established to curtail the loss of biodiversity. In southeastern Mexico, the largest patches of undisturbed tropical forests are located in the south of the Yucatán Peninsula. This natural feature was one of the main reasons the Mexican federal government established the Calakmul Biosphere Reserve (са. 723,185 ha) in the southernmost area of the Campeche state, Mexico (17 50’ $-19^{\circ} 25^{\prime} \mathrm{N}, 89^{\circ} 04^{\prime} 37^{\prime}$ - 9008' 31'’ W).

The dominant type of vegetation in the Calakmul Biosphere Reserve is tropical semideciduous forest with a canopy height averaging $25 \mathrm{~m}$. In addition, there are deciduous tropical forests, rain forests, seasonally flooded tropical forests, savannahs, reed beds, introduced grasslands for cattle, non-irrigated and irrigated farmlands, and secondary vegetation (March, 1994). The vegetation is taller_(ca. 30m) and more humid (1400 mm of annual precipitation) in the south of the reserve (Miranda, 1958). Lundell (1934), Miranda (1958) and Flores (1990) gave a detailed description of the Calakmul floristic composition. The climate is sub-humid warm, with an annual average temperature of $26^{\circ} \mathrm{C}$ and rainfall ranging from 600 to $1200 \mathrm{~mm}$ (García, 1988). The rainy season lasts from June to October (March, 1994).

In recent years, approximately 57 species of mammals have been recorded around and within the boundaries of the Calakmul Biosphere Reserve (Jones et al., 1973, 1974a, 1974b; Genoways and Jones, 1975; Sánchez and Romero, 1995; Hernández et al., 2000; Vargas-Contreras et al., 2002, 2005; Escalona-Segura et al., 2002). Of these 57 species, $17.5 \%$ represented new records for the state of Campeche. 
This fact enhances the need to intensify biotic inventories and a wide range of ecological research to increase our knowledge of the Yucatán Peninsula mammals.

The main goal of this note is to provide information about 12 species of mammals that inhabit southern Campeche, Mexico, and a new record from this state. Given the rarity of encountering some these species, we consider it important to document some observations made during two sampling seasons in the Calakmul region (August 1998 and July 1999) and another general surveys in the region (September 1998 and February 1999).

Grayish Mouse Oppossum - Tlacuatzin canescens canescens (J.A. Allen, 1893).

An individual was captured and photographed approximately $37 \mathrm{~km} \mathrm{~N}$ of the Calakmul archaeological ruins (“CAR”, $18^{\circ} 19^{\prime} \mathrm{N}, 89^{\circ}$ 51' W) on 6 June 1998. This individual was located in semideciduous tropical forest composed of "palo tinto" (Haematoxylon campechianum), "pucté” (Bucida buceras), "sisilché" (Gimnopodium floribundum) and "cascarillo" (Croton sp). A local ornithologist, Mauro Berlanga, found this small opossum in the vegetation while walking through the forest. Identifying key features of the individual were a small size, light brown fur coloration, and presence of dark ocular ring. This species has been previously recorded in the central-south region of the Yucatán state (Osgood, 1913; Tate, 1933; Hershkovitz, 1951; Hatt et al., 1953; Jones et al., 1974b; Hall, 1981). In addition, it is possible that a similar species of opossum, Marmosa mexicana, might be present in southern Campeche due to the similarity of some environmental conditions such as vegetation (sub-evergreen tropical forest) and temperature.

Greater White-lined Bat - Saccopteryx bilineata centralis (Thomas, 1904).

A non-reproductive male was collected on 15 February 1999, 60 km S of Dzibalchén, Campeche (19॰01' 48" N, 9000’ 48" W) in deciduous tropical forest. This individual was deposited in the Museo de Zoología, ECOSUR Unidad Chetumal (ECO CHM). Its measurements are 58.6-11-10.3-15.2=6g (total length - length of tail - length of hind foot - height of ear from notch, all of them in $\mathrm{mm}=$ body mass), forearm $(\mathrm{AB})=44.2$ (ECO CHM1728). This species was recorded in Campeche by Jones et al. (1973) $46 \mathrm{~km} \mathrm{~S}$ of Champotón; 1 km N and 13 km W of Escárcega; 65 km S and 128 km E of Escárcega. Other recent records in the Yucatán Peninsula are by Pozo and Escobedo (1999) who found it in the Sian Ka'an Biosphere Reserve, Quintana Roo; by Jones et al. (1973) in Chichén-Itzá, Yucatán; Sánchez and Romero (1995) in Tabasco; Dickerman et al. (1981) and McCarthy (1987) in Guatemala; McCarthy and Blake (1987), O'Farrel and Miller (1997), and Bârtschi (1998) in Belize. 
Davy's Naked-backed Bat - Pteronotus davyi (Gray, 1838).

We collected a non-reproductive adult female on 15 February 1999, $60 \mathrm{~km} \mathrm{~S}$ of Dzibalchén, Campeche ( $\left.19^{\circ} 01^{\prime \prime} 48^{\prime \prime} \mathrm{N}, 90^{\circ} 00^{\prime} 48^{\prime \prime} \mathrm{W}\right)$ in deciduous tropical forest. Its measurements are 69-23.4-10.5-17=6.5g, AB=45 (ECO CHM1711). Another individual was collected in Xbonil $\left(18^{\circ} 30.041=\mathrm{N}, 90^{\circ} 03.674=\mathrm{W}\right)$ in tropical semideciduous forest. Its measurements are 74-24-9-15=3.4g, AB=27.3 (ECO CHM 1865). Recent records for the Yucatán Peninsula are by Pozo and Escobedo (1999) in the Sian Ka'an Biosphere Reserve, and Álvarez and Álvarez (1991) 20.6 km S, 31.6 km W of Chetumal, Quintana Roo; Arita and Vargas (1995) for the municipalities of Tekax, Oxkutzkab, Opichén, and Hoctún, Yucatán; Jones et al. (1973) for Apazote, Champotón, and Escárcega, Campeche. The nearest record (5 km S of Champotón) to our collecting sites is located approximately $100 \mathrm{~km}$ NE of Dzibalchén and $100 \mathrm{~km}$ SE of Xbonil (Jones etal., 1973).

Orange-throated Bat - Micronycteris brachyotis (Dobson, 1879).

One non-reproductive female was collected on the 10 July 1999, $25 \mathrm{~km} \mathrm{~N}$ of CAR (18 $14^{\prime} \mathrm{N}, 89^{\circ} 48^{\prime} \mathrm{W}$ ) in semideciduous tropical forest. This individual was preserved in alcohol (ECO CHM1759), and its measurements are 65-11-9-12=12.5g, AB=41.2. This bat species has been recorded for southern Veracruz, Oaxaca and Chiapas (Schaldach, 1965; Davis et al., 1964, Medellín et al., 1983), but not for the Yucatán Peninsula. Our record is the second for the Yucatán Peninsula and the state of Campeche, after Hernández et al. (2000).

Schmidt’s Big-eared Bat - Micronycteris schmidtorum (Sanborn, 1835).

We caught five individuals, two of which were collected and deposited, one in ECO CHM1758 and the other in the Museo de Zoología de la Facultad de Ciencias, UNAM (MZFC 11178). The individual deposited in ECOSUR was a male subadult (in alcohol, $8.5 \mathrm{~g}, \mathrm{AB}=35)$ collected on 4 August, 1998 , approximately $37 \mathrm{~km} \mathrm{~N}$ of CAR $\left(18^{\circ} 19^{\prime} \mathrm{N}\right.$, $89^{\circ} 51^{\prime} \mathrm{W}$ ). The second specimen, a male with scrotal testis (61-12-8-23=8g, $\mathrm{AB}=34.3$ ), was caught on 5 July 1999, at the same study site. The other three individuals were captured, sexed, weighed, their $A B$ measured, and then released. Two of them, an adult female (13g, $\mathrm{AB}=36.5$ ) and an adult male (14.5g, $\mathrm{AB}=35)$, were mist-netted on 29 June 1999, about $16 \mathrm{~km}$ N of Conhuás (18 36' $\mathrm{N}, 89^{\circ} 52^{\prime} \mathrm{W}$ ). The fifth specimen was an

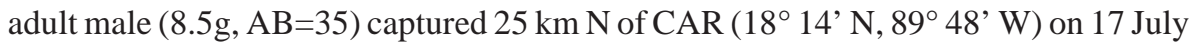
1999. All individuals were captured in semideciduous tropical forest. In the Yucatán Peninsula, this species has been recorded at the Cozumel island, Quintana Roo (Jones et al., 1973). This specimen was confirmed by McCarthy (1987) and the first author of this paper. 
There is also another record for the Dzilám de Bravo reserve (Hernández Betancourt et al., 1996). The most recent records of this species were taken by Pozo and Escobedo (1999) in the Sian Ka' an Biosphere Reserve and by third author in the Calakmul Biosphere Reserve. Our five individuals confirm the species's presence in souththern Yucatán Peninsula. However, its presence has not been documented in the centralwestern area of the Yucatán Peninsula. Apparently, these specimens show morphological differences with South American individuals of this species. Therefore, a taxonomic review is necessary.

Golden Bat - Mimon benettii cozumelae (Goldman, 1914).

We collected a non-reproductive adult female on 19 September 1998 in CAR (18 $06^{\circ}$ ' $37 " \mathrm{~N}, 89^{\circ} 48^{\prime} 21^{\prime \prime} \mathrm{W}$ ) in semideciduous tropical forest. Its measurements are 84.9-1715.3-29.8=23g, AB=58.8 (ECO CHM1680). Recent records for the Yucatán Peninsula come from Navarro et al. (1990) $36 \mathrm{~km} \mathrm{~S} \mathrm{of} \mathrm{Felipe} \mathrm{Carrillo} \mathrm{Puerto} \mathrm{in} \mathrm{Quintana} \mathrm{Roo;}$ Hernández Betancourt et al. (1996) reported it for the Dzilám de Bravo reserve, northern Yucatán; while Birney et al. (1974) found it in two localities in central and northeastern Yucatán; Arita and Vargas (1995) recorded this species in Actún Lol-tún Cave, Yucatán. In Campeche, this bat species had been recorded by Romero and Sánchez (1994) and Sánchez and Romero (1995) at the Haltunchén-Ruinas Edzná road; Jones et al. (1973) found it in Dzibalchén 2 km NE of Hopelchén. In Belize, this species was recorded by Bârtschi (1998), McCarthy (1987), and McCarthy and Blake (1987).

David's Round-eared Bat - Tonatia evotis (Davis and Carter, 1978).

Three individuals of this species were captured using mist nets; two of them were

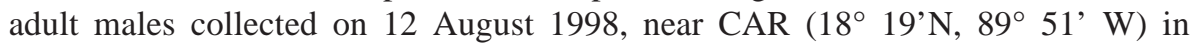
semideciduous tropical forest. The morphometric measurements for these individuals are 88-17-12-31=25g, $\mathrm{AB}=51$ (MZFC 11187) and 73-12-11.7-33=26g, $\mathrm{AB}=47.6$ (ECO CHM1587). On 28 June 1999, we mist-netted one more adult male (21.5g, AB 47.8) NW of Conhuás $\left(18^{\circ} 36=\mathrm{N}, 89^{\circ} 52=\mathrm{W}\right)$ in tropical semideciduous forest. There are very few records of this species natiowide. Davis and Carter (1978) mention four localities where individuals of T. evotis have been collected: Veracruz, Tabasco, Chiapas, and Campeche. Concerning previous records in the state of Campeche, it was collected $12 \mathrm{~km} \mathrm{~W}$ of Escárcega and our records come from a site located $86 \mathrm{~km}$ E of Escárcega. On the other hand, Sánchez et al. (1986) reported the presence of this species in Quintana Roo, 165 km NNE of our sites. Our three specimens had similar morphological characteristics to the one deposited in the collection of mammals at Natural History Museum, University of Kansas (KUNHM 93346), obtained by Davis and Carter (1978). Our records are the third from Campeche (after Jones et al., 1973, Hernández et al., 2000). 
Great Fruit-eating Bat - Artibeus lituratus palmarum (J.A. Allen and Chapman, 1897).

We captured three individuals of this species with mist nets. One of them was a lactating adult female, on 21 August 1998 in CAR (1806’ 37" N, 8948' 21" W) in semideciduous tropical forest. Its body measurements are 89-0-17.4-21=69g, $\mathrm{AB}=71$ (ECO CHM1576). The other two individuals were collected on 25 September 1998, $1 \mathrm{~km}$ S of Plan de Ayala (18 $\left.03^{\prime} 30^{\prime \prime} \mathrm{N}, 8^{\circ} 17^{\prime} 34^{\prime \prime} \mathrm{W}\right)$. These individuals were a nonreproductive adult male with body measurements of 90-0-20.5-20.5=65g, $A B=75$ (ECO CHM1664), and a lactating adult female with body measurement 93-0-18.5-21=71g, $\mathrm{AB}=71$ (ECO CHM1665). The vegetation where the latter two individuals were collected is tropical rain forest. In the Yucatán Peninsula, previous records are from Pozo and Escobedo (1999) who collected at 6 km S of Boca Paila in the Sian Ka'an Biosphere Reserve, Quintana Roo; Sánchez and Romero (1995) in Ciudad del Carmen, Campeche; and Hernández-Betancourt et al. (1996) in Dzilám de Bravo, northern Yucatán. Koopman (1993) considered A. intermedius and A. lituratus the same species. However, Davis (1984) revised the complex Artibeus lituratus in Central America and accepted A. intermedius as a valid separable species from A. lituratus. We agree with this species division and suggest further study to determine the new geographic distribution range of both species.

Common Tent-making Bat - Uroderma bilobatum molaris (Davis, 1968).

One adult male with scrotal testis was collected on 25 September 1998, $1 \mathrm{~km} \mathrm{~S} \mathrm{of} \mathrm{Plan}$ de Ayala, Campeche $\left(18^{\circ} 03^{\prime} 30^{\prime \prime} \mathrm{N}, 89^{\circ} 17^{\prime} 34^{\prime \prime} \mathrm{W}\right)$ in tropical rain forest. Its measurements are 66-0-7.3-6=12g, AB=39.8 (ECO CHM 1668). The first records for this species in the Yucatán Peninsula are from Sánchez et al. (1986) in the Ruinas de Konhulich, Quintana Roo. McCarthy (1987) recorded this species in Bacalar, Quinta Roo. From Campeche, the first record, and probably the only one, was given by Dowler and Engstrom (1988). They recorded seven individuals of this species $11 \mathrm{~km} \mathrm{~S}$ of Candelaria. This location is approximately $170 \mathrm{~km} \mathrm{~W}$ of our collection sites. We believe that it is likely to find this species at the border between Campeche, Mexico and Guatemala due to the vast forest continuity in this area and because Dickerman et al. (1981) recorded it in Guatemala.

Little Yellow-eared Bat - Vampyresa pusilla thyone (Thomas, 1909).

One non-reproductive adult male was collected on 25 September 1998, $1 \mathrm{~km} \mathrm{~S} \mathrm{of} \mathrm{Plan}$ de Ayala, Campeche $\left(18^{\circ} 03^{\prime} 30^{\prime \prime} \mathrm{N}, 8^{\circ} 17^{\prime} 34^{\prime \prime} \mathrm{W}\right)$ in tropical rain forest. Its body measurements are 40-0-8.5-8=6.5g, $\mathrm{AB}=30$ (ECO CHM 1669). Davis et al. (1964) 
recorded this species for first time in Chiapas, Mexico. Reid (1997) considered this species as absent from the Yucatán Peninsula, while Jones et al. (1973) recorded it 65 $\mathrm{km} \mathrm{S}, 128 \mathrm{~km}$ E of Escárcega. There are several records relatively close to our collecting site in Belize (McCarthy, 1987).

Tayra - Eira barbara (Linnaeus, 1758).

We found a male with scrotal testis (1140-470-103-48) recently killed on highway Escárcega-Chetumal at km $143\left(18^{\circ} 30^{\prime} \mathrm{N}, 8^{\circ} 9^{\circ} 9^{\prime} \mathrm{W}\right)$. Our record had the complete pattern of fur coloration explained by Reid (1997). We found the same phenotype variation in specimens deposited in the mammal collection of the Natural History Museum of the University of Kansas (KUMHN). Such specimens were collected from the Mexican states of Campeche (KUMHN 95113), Chiapas (KUMHN 66216), and Veracruz (KUMHN 24544-24545). However, Reid (1997) indicates that the pale-brown head form, with a diamond on the throat and dark brown body is found only from Honduras to Panama. Krumbiegel (1942) stated that the diamond-shape spot on the throat is not a reliable feature to separate the subspecies because its presence is part of the intrapopulation variation. We strongly suggest a taxonomic revision of this species of mustelid to define the distributional limits of the subspecies in Mexico and Central America.

Yucatan Vesper Mouse - Otonyctomys hatti (Anthony 1932).

We accidentally captured a female (203-113-16-13=27g; ECO CHM1761) 5 km N of Conhuás (18³6' N, 89 52' W) on June 271999 in semideciduous tropical forest. It was found tangled and hanging up side down from a mist net just before opening it for a bird survey. Apparently, there are very few records of the species, which is endemic to the Yucatán Peninsula. This specimen has a size and fur coloration similar to those deposited in the KUMHN (KUMHN 93870, from N Campeche; and KUMHN 92356, from NE Yucatán) cited by Jones et al. (1974) and Anthony (1932). Navarro et al. (1990) recorded O. hatti for first time in central Quintana Roo; till recently Aranda et al. (1997) recorded this species for northern Quintana Roo. Our record is the fourth for the state of Campeche (Jones et al., 1974; Hall, 1981; Hernández et al., 2000).

These results partly come from a research supported by a grant of NAWCC (278-1478). We are very thankful to Héctor Garza, Alfonso Torres, Hugo Hernández, Alfredo Hernández, Dionisio Rodríguez, and several local people for their assistance in the field. We also want to thank Griselda Escalona, Joaquín Arroyo and David Bonter for their constructive comments on the manuscript. To Bob Timm and Thor Holmes for allowing us to review specimens in the mammal collection of the Natural History Museum of the University of Kansas. 


\section{LITERATURECITED}

Anthony, H.E. 1932. A new genus of rodents from Yucatán. American Museum Novitates, 586:275-277.

Aranda, M., J.E. Escobedo y C. Pozo de la T. 1997. Registros recientes de Otonyctomys hatti (Rodentia:Muridae) en Quintana Roo, México. Acta Zoológica Mexicana (n. s.), 72:63-65.

Arita, H.A. y J.A. Vargas. 1995. Natural history, interspecific association, and incidence of the cave bats of Yucatán, México. Southwestern Nataturalist, 40:29-37.

Bârtschi, D. 1998. Chiroptéres de la Réserve Naturelle de Shipstern et de ses environs (Nord du Bélize): Inventaire et biologie. Université de Neuchatel. Faculté des Sciences.Travil de Diplôme.

Birney, E.C., J.B. Bowles y R.M. Timm. 1974. Mammalian distributional records in Yucatán and Quintana Roo, with comments on reproduction, structure, and status of Peninsular populations. Bulletin of the Museum Natural History, University of Minnesota, Occasional Paper, 13:1-25.

Davis, W.B., D.C. Carter y R.H. Pine. 1964. Noteworthy records of Mexican and Central American bats. Journal of Mammalogy, 45:375-387.

Davis, W.B. y D.C. Carter. 1978. A review of the round-eared bats of the Tonatia silvicola complex, with descriptions of three new taxa. Occasional Papers of the Museum, Texas Tech University, 53:1-12.

Davis, W.B. 1984. Review of the large fruit-eating bats of the "Artibeus lituratus" complex (Chiroptera: Phyllostomidae) in Middle America. Occasional Papers of the Museum, Texas Tech University, 93:1-16.

Dickerman, R.W., K.F. Koopman y C. Seymour. 1981. Notes on bats from the Pacific lowland of Guatemala. Journal of Mammalogy, 62:406-411.

Dowler, R.C. y M.D. Engstrom. 1988. Distributional records of mammals from the southwestern Yucatán Peninsula of Mexico. Annals of Carnegie Museum, 57:159-166.

Escalona-Segura, G., J. A. Vargas-Contreras y L. Interián-Sosa. 2002. Registros importantes de mamíferos para Campeche, México. Revista Mexicana de Mastozoología 6:99-103.

Flores, S. 1990. Reporte preliminar de la vegetación de la Reserva de la Biosfera de Calakmul, Campeche. Universidad Autónoma de Yucatán. Mérida, Yucatán. Manuscrito.

García, E. 1988. Modificaciones al sistema de clasificación climática de Köppen. Instituto de Geografía. UNAM. México, D.F.

Genoways, H.H. y J.K. Jones Jr. 1975. Annotated checklist of mammals of the Yucatán Peninsula, Mexico. IV. Carnivora, Sirenia, Perissodactyla, Artiodactyla. Occasional Papers of the Museum, Texas Tech University, 26:1-22.

Hall, E. R., 1981. The Mammals of North America. John Wiley \& Sons. 2nd. ed. U.S.A. 1811pp. 2vol.

Hatt, R.T., H.I. Fisher, D.A. Langebartel y G.W. Brainerd. 1933. Faunal and archeological researches in Yucatán caves. Bulletin Cranbrook Institute Science, 33:1-119.

Hershkovitz, P. 1951. Mammals from British Honduras, Mexico, Jamaica and Haiti. Fieldiana Zoology, 31:547-569. 
Hernández-Betancourt, S., V. Sánchez-Cordero, J. Sosa Escalante y A. Segovia Castillo. 1996. VIII. Lista anotada de los mamíferos terrestres de la Reserva de Dzilám, Yucatán, México. Listados faunísticos de México. Instituto de Biología, Universidad Nacional Autónoma de México. México, D. F.

Hernández, A., V.J. Sosa, J.M. Aranda y J. Bello. 2000. Noteworthy records of small mammals from the Calakmul biosphere reserve in the Yucatán Peninsula, Mexico. Southwestern Naturalist, 45:340-344.

Jones, J.K. Jr. 1966. Bats from Guatemala. University of Kansas Publication, Museum of the Natural History, 16:439-472.

Jones, J.K. Jr., H.H. Genoways y T.E. Lawlor. 1974a. Annotated checklist of mammals of the Yucatán Peninsula, Mexico. II. Rodentia. Occasional Papers of the Museum, Texas Tech University, 22:1-31.

Jones, J.K. Jr., H.H. Genoways y J.D. Smith. 1974b. Annotated checklist of mammals of the Yucatán Peninsula, Mexico. III. Marsupialia, Insectivora, Primates, Edentata, Lagomorpha Occasional Papers of the Museum, Texas Tech University, 23:1-12.

Jones, J.K. Jr., J.D. Smith y H.H. Genoways. 1973. Annotated checklist of mammals of the Yucatán Peninsula, Mexico. I. Chiroptera. Occasional Papers of the Museum, Texas Tech University, 13:1-31.

Koopman, K.F. 1993. Order Chiroptera. Pp. 137 B 241, en: Mammal species of the world : $a$ taxonomic and geographic reference. (D.E. Wilson and D.M. Reeder, eds.). $2^{\text {nd }}$. ed. Smithsonian Institution Press. U.S.A.

Krumbiegel, V.I. 1942. Die Säugetiere der Südamerika-Expeditionen Prof. Dr. Kriegs. Zoological Anzeiger, 139(5/6):81-108.

Lundell, C.L. 1934. Preliminary sketch of the phytogeography of the Yucatán Peninsula. Carnegie Institute Washington Publication, 436:257-321.

March M. I.J. 1994. Situación actual del Tapir en México. Centro de Investigaciones Ecológicas del Sureste. Serie Monográfica. 1:37.

McCathy, T.J. 1987. Distributional records of bats from the Caribbean lowlands of Belize and adjacent Guatemala and Mexico. Pp. 137-162, en: Studies in Neotropical mammalogy : essays in honor of Philip Hershkovitz. (B.D. Patterson and R.M. Timm, eds.). Fieldiana Zoology (n.s.), 39:1-506.

McCarthy, T.J. y M. Blake. 1987. Noteworthy records from the Maya Mountains Forest Reserve, Belize. Mammalia, 51: 161-164.

Medellín, R.A., D. Navarro, W.B. Davis y V.J. Romero. 1983. Notes on biology of Micronycteris brachyotis (Dobson)(Chiroptera), in southern Veracruz, México. Brenesia, 21:7-11.

Miranda, F. 1958. Estudios acerca de la vegetación. Pp. 215-271, en: Los recursos naturales del sureste y su aprovechamiento. Ediciones del Instituto Mexicano de Recursos Naturales Renovables. México, D.F., Vol. 2.

Navarro, D., T. Jiménez A. y J. Juárez G. 1990. Los mamíferos de Quintana Roo. Pp. 371-450, en : Diversidad biológica en la reserva de la biosfera de Sian Ka' an, Quintana Roo, México. (D. Navarro y J.G Robinson, eds.) Centro de Investigaciones de Quintana Roo, Chetumal, México. 
O’Farrell, M.J. y B.M. Miller. 1997. A new examination of echolocation calls of some neotropical bats (Emballonuridae and Mormoopidae). Journal of Mammalogy, 78:954963.

Osgood, W.H. 1913. Two new mouse opossums from Yucatán. Proceeding of the Biological Society Washington, 26:175-176.

Pozo de la T., C. y E. Escobedo C. 1999. Mamíferos terrestres de la Reserva de la Biosfera de Sian Ka’ an, Quintana Roo, México. Revista de Biología Tropical, 47(1-2):251-262.

Reid, F.A. 1997. A field guide to the Mammals of Central America and Southeast Mexico. Oxford University Press.

Sánchez H., C. y M. L. Romero. 1995. Murciélagos de Tabasco y Campeche una propuesta para su conservación. CUADERNOS 24. Instituto de Biología, Universidad Nacional Autónoma de México.

Sánchez H., O., G. Tellez G., R.A. Medellín y G. Urbano V. 1986. New records of mammals from Quintana Roo, México. Mammalia, 50:275-277.

Schaldach, W.J. Jr.. 1965. Notas breves sobre algunos mamíferos del sur de México. Anales del Instituto de Biología, Universidad Nacional Autónoma de México, 35:129-137.

Tate, G.H.H. 1933. A systematic revision of the marsupial genus Marmosa, with a discussion of the adaptative radiation of the murine opossums (Marmosa). Bulletin of the American Museum Natural History, 64:1-250.

Vargas-Contreras, J. A., J. Arroyo-Cabrales, M. Sanvicente-López y R. Reyna-Hurtado. 2002. Nuevos registros de mamíferos para Campeche. Vertebrata Mexicana, 11:17-20.

Vargas-Contreras, J. A., G. Escalona-Segura, J. Arroyo-Cabrales, R. R. Calderón-Mandujano, L. Interián-Sosa y R. Reyna-Hurtado. 2005. Especies prioritarias de vertebrados terrestres en Calakmul, Campeche. Vertebrata Mexicana, 16:11-32. 